\title{
Ortaokul Beden Eğitimi ve Spor Dersi Öğretim Programı Kazanımlarının 21. Yüzyıl Becerileri Açısından İncelenmesi
}

\author{
M. Enes IŞIKGÖZ1
}

Atıf/C): Işıkgöz, M.. E. Ortaokul Beden Eğitimi ve Spor Dersi Öğretim Programı Kazanımlarının 21. Yüzyıl Becerileri Açısından İncelenmesi, Artuklu İnsan ve Toplum Bilim Dergisi 2021/6 (1), 71-84.

Öz

Bu çalışmada Ortaokul (5, 6, 7 ve 8. Sınıflar) Beden Eğitimi ve Spor Dersi Öğretim Programı kazanımlarının 21. yüzyıl becerileri açısından incelenmesi amaçlanmıştır. Çalışma nitel araştırma olarak desenlenmiş ve doküman incelemesi yönteminden yararlanılmıştır. Araştırmanın dokümanını Ortaokul $(5,6,7$ ve 8 . Sınıflar) Beden Eğitimi ve Spor Dersi Öğretim Programı oluşturmaktadır. Doküman kapsamında öğretim programında yer alan kazanımlar; 21. yüzyıl becerileri açısından içerik analizine tabi tutularak her bir kazanımın, ilişkili olabileceği 21. yüzyıl becerisi altında kodlanmıştır. Excel programında kodlanan veriler analiz edilerek sayı ve yüzde olarak tablo ve grafikler halinde sunulmuştur. Çalışman sonucunda; ortaokul beden eğitimi ve spor dersi öğretim programında yer alan 122 kazanımda, toplam $208 \mathrm{kez}$ " 21 . yüzyıl becerisine" değinildiği, bazı kazanımlarda birden çok beceriye vurgu yapıldığı görülmüştür. Programda en çok eleştirel düşünme ve problem çözme becerilerinin ön plana çıktığı, en az ise medya ve bilgi okuryazarlığı becerilerine yer verildiği, teknoloji okuryazarlığı becerilerine ise hiç yer verilmediği saptanmıştır. Programın "Hareket Yetkinliği” ve "Aktif ve Sağlıklı Hayat" öğrenme alanı kazanımlarında öğrenme ve yenilikçilik becerileri ile yaşam ve kariyer becerileri tüm sınıf düzeylerinde yer alırken, bilgi, medya ve teknoloji becerileri ise sadece 7. ve 8.sinıf kazanımlarında yer almıştır.

Anahtar Kelimeler: Ortaokul, Beden eğitimi ve spor öğretim programı, 21. yüzyıl becerileri.

\section{Analysis on the Acquisitions of Secondary School Physical Education and Sports Lesson Curriculum in Terms of the 21st Century Skills}

Atıf/C): Işılkgöz, M.. E. Analysis on the Acquisitions of Secondary School Physical Education and Sports Lesson Curriculum in Terms of the 21st Century Skills, Artuklu İnsan ve Toplum Bilim Dergisi 2021/6 (1), 71-84.

\begin{abstract}
This study aims to examine the acquisitions of the Physical Education and Sports Lesson Curriculum of Secondary School (5th, 6th, 7th and 8th grades) in terms of the 21st century skills. The study was designed as qualitative research and a document analysis method was used. The document of the research consists of the Physical Education and Sports Lesson Curriculum of Secondary School (5th, 6th, 7th and 8th grades). The acquisitions in the curriculum within the scope of the document were subjected to content analysis in terms of the 21 st century skills and coded under the 21st century skills to which each acquisition can be related. The data encoded in the Excel program were analyzed and presented as numbers and percentages in tables and graphs. As a result of the study, it has been observed that "the 21 st century skill" is mentioned a total of 208 times in 122 acquisitions placed in the physical education and sports lesson curriculum of secondary school and more than one skill is emphasized in some acquisitions. It has been determined that critical thinking and problem-solving skills are the most prominent ones in the
\end{abstract}

${ }^{1}$ Doç. Dr. Mardin Artuklu Üniversitesi, Beden Eğitimi ve Spor Yüksekokulu, Beden Eğitimi ve Spor Bölümü, pdgenes@gmail.com, ORCID: orcid.org/0000-0001-7804-1011

Geliș/Received:08.04.2021 Kabul/Accepted:06.06.2021 


\section{Ortaokul Beden Ĕ̆itimi ve Spor Dersi Öğretim Programı Kazanımlarının 21. Yüzyıl Becerileri Açısından Íncelenmesi}

program, media and information literacy skills are the least mentioned, and technology literacy skills are not included at all. In the "Movement Competence" and "Active and Healthy Life" learning area acquisitions of the program, learning and innovation skills, and life and career skills are included in all grade levels while knowledge, media and technology skills are only included in the 7th and 8th grade acquisitions.

Keywords: Middle school, Physical education and sports curriculum, 21st century skills

\section{GİRIŞ}

Toplumsal değişim ve hareketlerin hızlı yaşandığı 21. yüzyıl aynı zamanda eğitim düşüncesinde köklü kırılma ve dönüşümlerin yaşandığı bir yüzyıl olmuştur. Bilimsel ve teknolojik ilerlemeler, küresel ölçekli bireysel özgürlükçü sosyo-politik değişimler, toplumsal refah için kalkınma çabaları ve küresel rekabet edilebilirlik ekseninde eğitim hep öne çıkan bir olgu olmuştur. Geçmişten günümüze felsefi açıdan eğitime olan bakış açısı sürekli değişmekte bu noktada eğitim sistemleri toplumsal beklentileri karşılayacak şekilde yeniden dizayn edilmektedir. Çünkü 21. yüzyılın getirdikleri ile baş etmek için tüm ülkelerin, insanlarını 21. yüzyıl taleplerini karşlayabilecek nitelikte yetiştirmeleri bir zorunluluk olarak ortaya çıkmakta ve görevler de eğitim sistemine düşmektedir (Tutkun, 2010). Dinamik bir süreç olarak ele alınan eğitim sistemlerinde çök yönlü değişim ve yenileşme gerçekleşmektedir. Özellikle eğitimin içeriği hayatla daha ilişkili olmaya başlamakta ve çok bilen insan yerine, bilgiye kolayca erişebilmenin de yollarını iyi bilen, bilgiyi yaşamı kolaylaştırmakta bir araç olarak kullanabilen insan yetiştirme giderek daha çok ön plana çıkmaktadır (Oğuz ve ark., 2010).

Bireyin doğumunun ardından kendini ve çevrini tanımasıyla başlayan eğitim, hayatının bir parçası haline gelir, onun için ömrünün sonuna kadar devam eden bir süreci kapsar (Karabacak, 2017). Eğitim süreci içerisinde bireyin, kendisini değişen koşullara uyarlayabilmesi, geleceği bütün ön görünümleriyle kavrayabilmesi, yaptığı işe eleştirel bir bakış açısı getirebilmesi ve yeni ilişkiler kurabilmesini sağlayacak bilgi ve becerilerle donatılması gerektirmektedir (Aykaç, ve ark., 2011). Günümüz bireyinden beklenen bilgiyi ezberine alması değil her alanda ona hızlı ulaşması, paylaşması ve onu etkin kullanması için bireyin önemsemesi ve geliştirmesi gereken belli beceriler bulunmaktadır (Hamarat, 2019). Çünkü bireylerin 21. yüzyıl istihdamında pay sahibi olabilmeleri için temel bilgi ve temel beceriler ile edindikleri okul diplomaları yeterli olmamakta, sahip oldukları temel becerilerinin ötesinde, 21. yüzyıl becerileri olarak adlandırabileceğimiz bir dizi beceriye sahip olmaları gerekmektedir (Eryllmaz ve Uluyol, 2015).

Bilgi toplumu olan bu yüzyılda, bireylerin iyi vatandaş ve nitelikli iş gören olmalarını sağlayan özellikler 21.yüzyıl becerileridir (Ananiadou ve Claro, 2009). Bu beceriler genel olarak girişimcilik, bilgi teknolojileri okuryazarlığı, eleştirel düşünme ve problem çözme, yaratıcıllk ve yenilik, işbirliği ve iletişim kurma, liderlik ve sorumluluk, esneklik ve uyumluluk başlıkları ile öne çıkmaktadır. Aslında eğitim olgusu içinde bireylere bir takım beceriler kazandırma hep olagelmiştir. Ancak çağın gerekleri ve dinamikleri sonucu belirli başlık ve gruplar halinde sistematize edilmeleri, sürekli güncellenmeleri yenidir. Özellikle 21. yüzyıl becerilerinin gelişmesinde 2015 "Dünya Ekonomik Forumu" etkili olmuş bu kapsamda küresel ihtiyaç ve beklentiler doğrultusunda on altı temadan oluşan "Yeni Eğitim Vizyonu: Teknoloji Sayesinde Sosyal ve Duygusal Öğrenmeyi Teşvik Etme" isimli çalışma geliştirilmiştir (Uçak ve Erdem, 2020).

Uluslararası ölçekte birçok kurum, kuruluş ve sivil toplum örgütünün, bilgi ve iletişim teknolojilerini kullanma, medya okuryazarlığı, sosyal yaşama uyum, eleştirel düşünme ve problem 
çözme, iletişim gibi başlıklar altında bireylerin sahip olması gereken 21. yüzyıl becerileri üzerinde çalışma yürüttükleri görülmektedir. Bu kapsamda Ekonomik İşbirliği ve Kalkınma Örgütü (OECD)'nin “2030'lı yıllarda öğrencilerin sahip olmaları gereken beceriler” (OECD, 2018), 2003 yılında Kuzey Merkez Bölgesel Eğitim Laboratuvarı (The North Central Regional Educational Laboratory-NCREL)'nin küreselleşme ve teknoloji ekseninde dört grupta belirlediği 21. yüzyıl becerileri (NCREL, 2003), 2008 yılında Avrupa Parlamentosu'nun kabul ettiği “Avrupa yeterlilikler çerçevesi" (EU, 2008), 2012 yılında "21. yüzyıl becerilerinin öğretilmesi ve değerlendirilmesi projesi (Assessment and Teaching of 21st Century Skills)" (Binkley ve ark., 2012) olduğu görülmektedir. Yine bu kapsamda 2010 yılında Ulusal Araştırma Konseyi (National Research Council-NRC) tarafından üç ana başlık altında belirlenen "21. yüzyıl becerileri” (NRC, 2010), Uluslararası Eğitim Teknolojileri Derneği (International Society for Technology in Education National Educational Technology Standards -ISTE) tarafindan eğitimde teknolojiyi etkili kullanmaya dönük öğrencilerin sahip olması gereken beceriler (ISTE, 2014) gibi benzer boyutlar altında 21 . yüzyıl becerilerini oluşturan birçok uluslararası kuruluş bulunmaktadır. $\mathrm{Bu}$ kuruluşların yanı sıra en çok kabul gören ve üzerinde en fazla akademik çalışma yapılan ABD' de 21 Eyalette uygulama alanı bulan ve 33 kurum ve kuruluş tarafından desteklenen "21. Yüzyıl Beceriler Çerçevesi- Partnership for 21st Century Skills (P21)" göze çarpmaktadır (P21, 2019). 21. Yüzyıl Becerileri Ortaklığı (Partnership for 21st Century Skills-P21); 2007 yılında ilgili paydaşların (eğitim iş görenleri, akademik çevre ve iş hayatı) düşüncelerini alarak, 21. Yüzyıl yeterliliklerini 3 grup altında 13 beceri olarak belirlemiştir (Şekil 1).

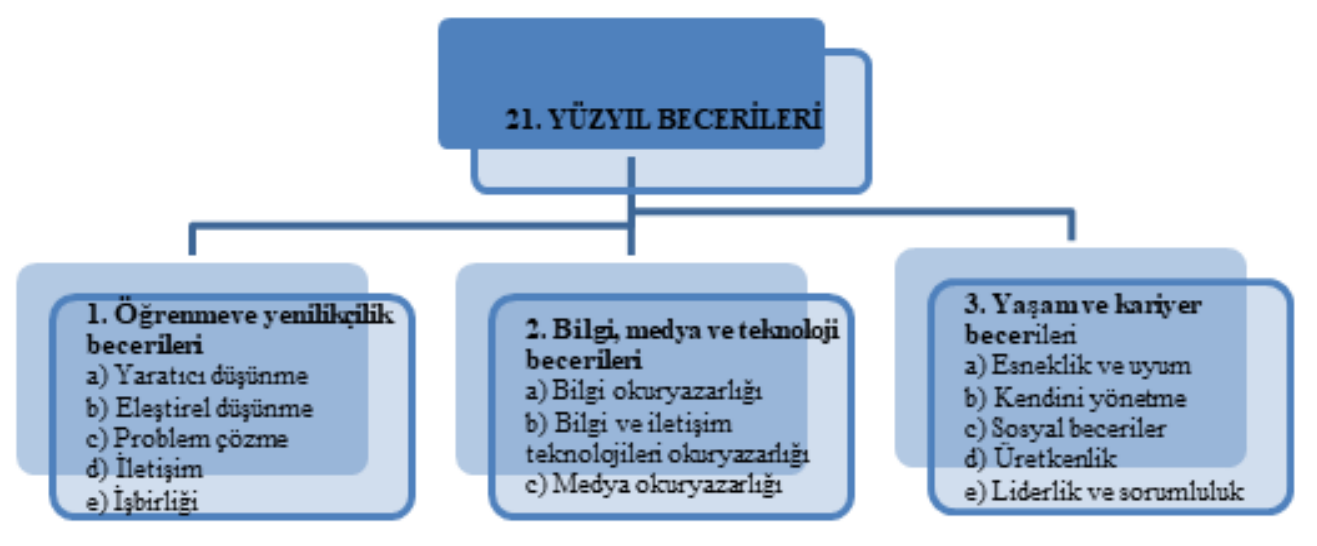

\section{Şekil 1: 21. Yüzyll Becerileri}

$\mathrm{Bu}$ becerilere genel olarak bakıldığında, hayat boyu öğrenmenin ve yaratıcı düşünmenin anahtarı olarak görülmektedirler (Trilling and Fadel, 2009). Öğrenme ve yenilik becerileri iş ortamlarına hazır olma ve daha da karmaşık hale gelen yaşama ilişkin öğrenmeyi ve yenilikçiliği geliştirmeyi ifade ederken, bilgi, medya ve teknoloji becerileri bireylerin hızla gelişen teknolojiye paralel olarak bilgi okuryazarlığı, medya okuryazarlığı gibi alanlarda sahip olmaları gereken bazı becerileri ifade etmektedir. Yaşam ve kariyer becerileri ise gerek iş dünyasında ve gerekse hayatta başarılı kalabilmek için bazı davranışları göstermeyi ifade eden becerileri içermektedir (Cansoy, 2018). 21. Yüzyıl Öğrenme Ortaklığı; bilgi aktarımı yerine, yaşam problemlerinin çözümü için gereken becerilerin kazandırılmasını hedeflemektedir. Öğrencilere; problemleri çözme, hayat boyu gelişim, yetkinleşme ve ustalık kazandırılması hedeflenmektedir. Araştırma ve sorgulama temelli, problem çözme odaklı, proje ve tasarım temelli bir öğrenme anlayışı doğrultusunda hareket ettiği anlaşılmaktadır (Uçak ve Erdem, 2020). Nitekim bilgi toplumunda insan bilgiyi araştıran, analiz edebilen, sentezleyen, objektif ve eleştirel düşünebilen, üretken, etkili konuşabilen, bireysel 


\section{Ortaokul Beden Ĕ̆itimi ve Spor Dersi Öğretim Programı Kazanımlarının 21. Yüzyıl Becerileri Açısından Íncelenmesi}

olduğu kadar grup çalışmalarında etkin, her koşulda yaratıcı düşünebilen özelliklere sahip insan diye tarif edilmektedir (Selvi, 2012).

Küresel ölçekli bu değişim ve dönüşüme ülkemizin de kayıtsız kalmadığı, eğitim ve öğretim alanında bir dizi değişimlerin yaşandığı görülmektedir. Özellikle paradigma değişimi şeklinde ilköğretim kademesinde 2004-2005 yılında öğretim programlarında köklü değişikliği gidilerek, programlarda bilgi aktarımı yerine yapılandırmacı yaklaşım temele alınmıştır (Çınar ve ark., 2006). Bu yaklaşım temelinde, Millî Eğitim Bakanlığının (MEB) değişen felsefesi doğrultusunda öğretim programlarını geliştirme, yenileme ve güncelleme çalışmaları 2005 'te yeni bir rayda başlamış, 2015-2016 eğitim öğretim yılında tamamlanmış, 2016-2017 eğitim öğretim yılının başından itibaren 51 müfredat ekseninde kapsamlı bir şekilde bir yenileme (güncelleme, gözden geçirme, ikmal ve değişiklik) çalışması yapılmıştır. 2017-2018 eğitim öğretim yılında 1, 5 ve 9. Sınıflarda yenilenen müfredatların uygulanmasına başlanmış, 2018-2019 tarihinde ise tüm sınıflarda ve tüm derslerde yeni müfredat ile eğitim öğretim sürecine geçilmiştir. Bakanlıkça öğretim programlarının yenilenmesinin gerekçesi olarak (MEB, 2017);

Toplumların teknoloji çağından bilgi çağına doğru geçmesiyle son yıllarda meydana gelen bilimsel, teknolojik, sosyal değişim ve gelişmeler ekseninde toplumun geleceğin üyelerinden beklentilerinin farklllaştı̆̆l, bu gelişme ve ilerlemeler öğrencilere temel bilgi ve becerilerin yanı sira eleştirel düşünme, özgün düşünme, araştırma yapma, sorun çözme gibi bilişsel; toplumsal ve kültürel katıllm, girişimcilik, iletişim kurma, empati kurma gibi sosyal; öz denetim, öz güven, kararlllık, liderlik gibi kişisel yeterlilik ve becerilerin kazandırılmasını zorunlu kıldığı ifade edilmiştir. Öğrencilerin hem ulusal hem de uluslararası düzeyde; kişisel, sosyal, akademik ve iş hayatlarında ihtiyaç duyacakları yeterlilik ve beceriler ile bunlara iliş̧in tanımlamalar çeşitli belgelerde tanımlandiğl, bu bağlamda Avrupa Parlamentosu ve Konseyi tarafindan 2008 yllinda kabul edilen "Avrupa Yeterlilikler Çerçevesi", "Millî Eğitim Kalite Çerçevesi”, "Türkiye Yeterlilikler Çerçevesi" ve "21. Yüzyll Becerileri" olarak anılan yeterlilik ve beceriler ile bunlara ilişkin açıklamalar dikkate alınmıştır. Müfredatlarla öğrencilere kazandırllması hedeflenen yeterlilik ve beceriler: anadilde iletişim, yabancı dillerde iletişim, matematik yeterliği, bilim ve teknoloji yeterliği, dijital yeterlik, ögrenmeyi ögrenme, inisiyatif alma ve girişimcilik algısl, sosyal ve kamusal yeterlikler, kültürel farkindalık ve ifade şeklinde belirlenmiştir. Bu yeterlilik ve beceriler, müfredatlarda disiplin alanlarının kazanımlarına ve/veya açıklamalarına doğrudan yahut dolaylı olarak ilişsilendirilmiş, 21. yüzyll becerileri olarak adlandırllan ve yeni yüzyllın mezunlarının sahip olması beklenilen yeterlilik ve beceriler de kazanımların ve kazanım açıklamalarının yapılandırılmasında göz önünde bulundurulmuştur.

MEB' in araştırma ve geliştirme (Ar-Ge) birimi olan "Eğitimi Araştırma ve Geliştirme Dairesi Başkanlığı (EARGED)" nın 2010 yılında yürütmüş olduğu "MEB 21.Yüzyıl Öğrenci Profili" başlıklı çalışmasında 21. yüzyıl becerileri; bilgi, beceri, tutum, değer ve etik temelinde, "Düşünme Yolları, Çalışma Yolları, Çalışma Araçları ve Dünya Vatandaşlı̆̆ı" başlıkları altında dört temada ele alındığı görülmektedir. "Düşünme Yolları" temasında; yaratıcılık ve yenilikçi düşünme ve bunlara açık olma, eleştirel düşünme, problem çözme ve karar verme, öğrenme stratejilerini kullanma/öğrenmeyi öğrenme ve üst bilişsel beceriler kendini değerlendirme becerilerine, "Çalışma Yolları" temasında; iletişim becerileri /Türkçeyi doğru kullanma ve bir yabancı dili temel düzeyde kullanma, takım çalışması becerilerine, "Çalışma Araçları" temasında; bilgi okuryazarlığı, bilgi iletişim teknolojileri okuryazarlığı becerilerine, "Dünya'ya Entegrasyon" temasında ise yerel ve evrensel vatandaşlık bilinci, yaşam ve kariyer ile ilgili bilinç ve becerileri, kültürel farkındalıkları ve yeterlikleri kapsayacak şekilde kişisel ve sosyal sorumluluk bilinci becerilerine yer verilmiştir (MEB, 2011). Bu çalışmanın da konusunu oluşturan Beden Eğitimi ve 
Spor Dersi (Ortaokul 5, 6, 7 ve 8. Sınıflar) Öğretim Programının perspektifinde ise eğitim sistemimizin temel amacının değerlerimiz ve yetkinliklerle bütünleşmiş bilgi, beceri ve davranışlara sahip bireyler olarak yetiştirmek şeklinde ifade edilmiştir (MEB, 2018b).

MEB'in 2018 yılında açıkladı̆̆ı “2023 Eğitim Vizyonu”’nda, 21. yüzyıla dair eğitim önerisi, 21. Yüzyıl Talim ve Terbiye Modeli şeklindeki çift kanatlı bir okumadır. Sadece beceri kazandırmak hayatı göğüslemeye yetmemektedir. Gerekli olan insana ait evrensel, yerel, maddi, manevi, mesleki, ahlaki ve millî tüm değerleri kapsayan ve kuşatan bir olgunlaşma, gelişme, ilerleme, değişim ve ahlak güzelliğidir şeklinde vurgulamıştır. Vizyon belgesinde, 21. yüzyıl becerileri arasında yer alan çoklu okuryazarlıklara (dijital, finansal, sağlık, ekoloji ve sosyal medya gibi vb.) ilişkin farkındalık ve beceri eğitimlerinin yanı sıra 21. yüzyıl becerileri için toplumsal sorun alanlarıyla birlikte bireysel ve mesleki gelişime yönelik farkındalık ve yetkinlik kazanılmasına dair etkinliklerin düzenleneceği, yükseköğretim kurumlarıyla iş birliği içinde 21 . yüzyıl becerilerini kazandırmak üzere ihtiyaç duyulan alanlarda öğretmenlere yönelik lisansüstü düzeyde yan dal programlarının açılacağı belirtilmiştir (MEB, 2018b). Öte taraftan 21. Yüzyıl becerileri kapsamında ülkemiz Türk Sanayicileri ve İşadamları Derneği (TÜSİAD) tarafından 26 Haziran 2012 tarihinde "21. Yüzyıl Becerileri ve Eğitimin Niteliği Toplantı Dizisi” başlatılmış, 21. yüzyıl becerilerinin öğrencilere kazandırılması için eğitim sisteminde atılabilecek adımlar konusunda çeşitli öneriler getirilmiştir (TÜSİAD, 2012).

21. yüzyıl becerilerinin öğrencilere kazandırılmasında eğitim sisteminin tüm öğelerinin kuşkusuz ayrı bir yeri ve önemi vardır. Ancak sistematik bir biçimde bu becerilerin öğrencilere bir bütünlük içerisinde kazandırılmasında öğretim programları önemli bir yer tutmaktadır. Bu noktada öğretim programlarının temel hedefi, özel olarak okul bilgisi ile günlük hayatta karşılaşılan sorunları çözebilecek bilgi ve becerilere sahip bireyler yetiştirmek, genel olarak ise 21. yüzyıl becerilerinin alt yapısını oluşturacak beceriler geliştirmek olmalıdır (Çepni, 2018). Nitekim ögrencileri geleceğe hazırlamada önemli beceriler olarak ortaya çıkan 21. yüzyıl becerilerine olan ilgi her geçen gün artmaktadır (Gelen, 2017). Alan yazın incelendiğinde öğretim programlarının 21. yüzyıl becerileri açısından incelendiği çalışmaların olduğu görülmektedir. Barası ve Erdamar (2021) ortaokul Türkçe dersi öğretim programını, Yalı (2021) 21. yüzyıl becerileri perspektifinden tarih eğitiminin yönünü, Kalemkuş (2021) fen bilimleri dersi öğretim programı kazanımlarını, Çetin ve Çetin (2021) 21. yüzyıl becerileri açısından MEB okul öncesi eğitim programını ve etkinlik kitabını, Kardeş (2020) ve Koçin ve Tuğluk (2020) okul öncesi eğitim programını, Gelişli ve Doğan (2020) Türk Dili ve Edebiyatı ortaöğretim programını, Kurudayığlu ve Soysal (2019) ise 2018 Türkçe dersi öğretim programı kazanımlarını 21. yüzyıl becerileri açısından inceledikleri çalışmalar göze çarpmaktadır. Ancak ortaokul ve lise düzeyinde beden eğitimi ve spor dersi öğretim programlarının 21. yüzyıl becerileri açısından incelendiği bir çalışmaya rastlanılmamıştır. Bu kapsamda bu çalışmanın alan yazına katkı sağlayacağı düşünülmektedir.

Bu çalışmanın amacı; Ortaokul $(5,6,7$ ve 8 . Sınıflar) beden eğitimi ve spor dersi öğretim programı kazanımlarının 21. yüzyıl becerileri açısından incelenmesidir. $\mathrm{Bu}$ amaç doğrultusunda aşağıdaki sorulara cevap aranmıştır;

1- Ortaokul $(5,6,7$ ve 8 . Sınıflar) beden eğitimi ve spor dersi öğretim programı kazanımlarında 21. yüzyıl becerileri genel olarak nasıl bir dağılım göstermektedir?

2- 2- Ortaokul (5, 6, 7 ve 8. Sınıflar) beden eğitimi ve spor dersi öğretim programının kazanımlarında 21. yüzyıl becerileri öğrenme ve alt öğrenme alanları ve sınıf düzeylerine göre nasıl bir dağılım göstermektedir?

\section{Yöntem}




\section{Ortaokul Beden Ĕ̆itimi ve Spor Dersi Öğretim Programı Kazanımlarının 21. Yüzyıl Becerileri Açısından İncelenmesi}

Ortaokul $(5,6,7$ ve 8 . Sinıflar) Beden Eğitimi ve Spor Dersi Öğretim Programı kazanımlarının 21. yüzyıl becerileri açısından incelendiği bu çalışmada, nitel araştırma yöntemlerinden doküman incelemesi tekniğinden yararlanılmıştır. Doküman incelemesinde araştırma konusu olan olay ve olgulara ilişkin bilgileri bulunduran yazılı kaynaklardan yararlanılır. Dokümanlar; yazılı halde bulunan metinlerden oluşan her tür doküman, görüntü ve ses kayıtları ile diğerleri kapsamında yer alan objeler, kalıntılar makro ve mikro düzeydeki veriler olarak gruplandırılır (Yıldırım ve Şimşek, 2006). Araştırmanın dokümanını Ortaokul (5, 6, 7 ve 8 . Sınıflar) Beden Eğitimi ve Spor Dersi Öğretim Programı (MEB, 2018a) oluşturmaktadır. Çalışma doküman incelemesi kapsamında olduğu için etik kurul izni alınmamıştır.

Öğretim Programında yer alan kazanımlar; 21. yüzyıl becerileri açısından içerik analizine tabi tutulmuşlardır. İçerik analizi birbirine benzeyen verileri belirli kavramlar ve temalar çerçevesinde bir araya getirmek ve bunları okuyucunun anlayabileceği bir şekilde düzenleyerek yorumlama olarak tanımlanmaktadır (Yıldırım ve Şimşek, 2006). Üç farklı grupta yer alan 21. yüzyıl becerilerinin "Öğrenme ve Yenilik Becerileri” grubunda; eleştirel düşünme ve problem çözme, yaratııllık ve yenilik, iş birliği ve iletişim becerileri, "Bilgi, Medya ve Teknoloji Becerileri” grubunda; bilgi okuryazarlığı, medya okuryazarlığı ve bilgi-iletişim-teknoloji okuryazarlığı becerileri, son grup olan "Yaşam ve Kariyer Becerileri" grubunda ise; esneklik ve uyum, girişim ve özyönetim, sosyal ve kültürler arası beceriler, verimlilik ve hesap verebilirlik, liderlik ve sorumluluk becerileri yer almaktadır (Partnership for 21st Century Skills-P21, 2016).

Tüm sınıf düzeylerinde yer alan her bir kazanım ilgili olabileceği 21. yüzyıl becerisi altında kodlanmıştır. Bazı kazanımların birden fazla beceri altında yer alabileceği görülmüştür. Kod güvenirliğinin sağlanması açısından ayrıca mesleki tecrübeye sahip iki beden eğitimi öğretmeni tarafından da kazanımların 21. yüzyıl becerileri altında tekrar kodlanması sağlanmış, yapılan hesaplamada kodlamalar arasındaki görüş birliği \% 84,5 olarak bulunmuştur. İçsel tutarlılık için kodlayıcılar arası görüş birliğinin en az \% 80 olması beklendiğinden (Miles ve Huberman, 1994), gerekli görüş birliğinin sağlandığı söylenebilir. Excel programı yardımıyla kodlanan veriler analiz edilerek tablo ve grafikler halinde sunulmuştur.

\section{Bulgular}

Tablo 1: Öğretim programı kazanımlarında 21. yüzyıl becerilerinin genel dağılımı

Tablo 1. Öğretim programı kazanımlarında 21. yüzyıl becerilerinin genel dağılımı

\begin{tabular}{|c|c|c|c|c|c|c|}
\hline \multirow[t]{2}{*}{ Sinif } & \multirow{2}{*}{$\begin{array}{c}\text { Kazanım } \\
\text { Sayısı }\end{array}$} & \multirow{2}{*}{$\begin{array}{c}\text { Öğrenme ve } \\
\text { Yenilikçilik } \\
\text { Becerileri }\end{array}$} & \multirow{2}{*}{$\begin{array}{c}\text { Bilgi, Medya } \\
\text { ve Teknoloji } \\
\text { Becerileri }\end{array}$} & \multirow{2}{*}{$\begin{array}{l}\text { Yaşam ve } \\
\text { Kariyer } \\
\text { Beceriler }\end{array}$} & \multicolumn{2}{|c|}{ Toplam } \\
\hline & & & & & $\mathrm{n}$ & $\%$ \\
\hline 5 & 31 & 25 & 0 & 28 & 53 & 25,48 \\
\hline 6 & 31 & 22 & 0 & 28 & 50 & 24,04 \\
\hline 7 & 30 & 27 & 1 & 22 & 50 & 24,04 \\
\hline 8 & 30 & 25 & 1 & 29 & 55 & 26,44 \\
\hline Toplam & 122 & 99 & 2 & 107 & $208^{*}$ & 100,0 \\
\hline
\end{tabular}

Tablo 1 incelendiğinde ortaokul beden eğitimi ve spor dersi öğretim programında tüm sınıf düzeylerinde toplam 122 kazanımın yer aldığı ve bu kazanımlardan bazılarının birden çok beceriyle ilişkili olduğu, bu kapsamda kazanımlarda 208 kez "21. yüzyıl becerisine" temas ettiği görülmüştür. Programda 21. yüzyıl becerileri içerisinde en çok yaşam ve kariyer becerilerine 
(107), sonra öğrenme ve yenilikçilik becerilerine (99), en az ise 2 kazanımda bilgi, medya ve teknoloji becerilerine temas ettiği tespit edilmiştir. Yine tablo 1 verilerine göre; 21.yüzyıl becerilerine 8 .sinıflarda $(\% 26,44), 6$. ve 7 . Sinıflarda $(\% 24,04)$, 5.sinıflarda $(\% 25,48)$ oranında vurgu yapıldığı görülmektedir.

Tablo 2: Öğretim programının ögrenme ve alt ögrenme alanı kazanımlarına göre 21. yüzyll becerilerinin dağılım

\begin{tabular}{|c|c|c|c|c|c|}
\hline ڤ & $\begin{array}{l}\text { Öğrenme } \\
\text { Alanı }\end{array}$ & $\begin{array}{l}\text { Alt } \\
\text { Öğrenme Alanı* }\end{array}$ & $\begin{array}{c}\text { Öğrenme ve } \\
\text { Yenilikçilik } \\
\text { Becerileri }\end{array}$ & $\begin{array}{c}\text { Bilgi, } \\
\text { Medya ve } \\
\text { Teknoloji } \\
\text { Becerileri }\end{array}$ & $\begin{array}{c}\text { Yaşam ve } \\
\text { Kariyer } \\
\text { Becerileri }\end{array}$ \\
\hline \multirow{9}{*}{5} & \multirow{4}{*}{ 1. Hareket Yetkinliği } & Toplam & 17 & 0 & 16 \\
\hline & & $\mathrm{HB}$ & 8 & 0 & 6 \\
\hline & & HKİB & 7 & 0 & 8 \\
\hline & & HST & 2 & 0 & 2 \\
\hline & \multirow{5}{*}{$\begin{array}{l}\text { 2. Aktif ve Sağlıklı } \\
\text { Hayat }\end{array}$} & Toplam & 8 & 0 & 12 \\
\hline & & DFE & 0 & 0 & 1 \\
\hline & & FKİB & 7 & 0 & 6 \\
\hline & & KBD & 1 & 0 & 5 \\
\hline & & Genel Toplam & 25 & 0 & 28 \\
\hline \multirow{9}{*}{6} & \multirow{4}{*}{ 1. Hareket Yetkinliği } & Toplam & 17 & 0 & 18 \\
\hline & & $\mathrm{HB}$ & 8 & 0 & 9 \\
\hline & & HKİB & 7 & 0 & 7 \\
\hline & & HST & 2 & 0 & 2 \\
\hline & \multirow{5}{*}{$\begin{array}{l}\text { 2. Aktif ve Sağlıklı } \\
\text { Hayat }\end{array}$} & Toplam & 5 & 0 & 10 \\
\hline & & DFE & 0 & 0 & 1 \\
\hline & & FKİB & 4 & 0 & 4 \\
\hline & & KBD & 1 & 0 & 5 \\
\hline & & Genel Toplam & 22 & 0 & 28 \\
\hline \multirow{9}{*}{7} & \multirow{4}{*}{ 1. Hareket Yetkinliği } & Toplam & 20 & 0 & 13 \\
\hline & & $\mathrm{HB}$ & 8 & 0 & 9 \\
\hline & & HKİB & 11 & 0 & 4 \\
\hline & & HST & 1 & 0 & 0 \\
\hline & \multirow{5}{*}{$\begin{array}{l}\text { 2. Aktif ve Sağlıklı } \\
\text { Hayat }\end{array}$} & Toplam & 7 & 1 & 9 \\
\hline & & DFE & 2 & 0 & 1 \\
\hline & & FKİB & 4 & 1 & 4 \\
\hline & & KBD & 1 & 0 & 4 \\
\hline & & Genel Toplam & 27 & 1 & 22 \\
\hline \multirow{9}{*}{8} & \multirow{4}{*}{ 1. Hareket Yetkinliği } & Toplam & 18 & 0 & 17 \\
\hline & & $\mathrm{HB}$ & 5 & 0 & 5 \\
\hline & & HKİB & 12 & 0 & 11 \\
\hline & & HST & 1 & 0 & 1 \\
\hline & \multirow{5}{*}{$\begin{array}{l}\text { 2. Aktif ve Sağlıklı } \\
\text { Hayat }\end{array}$} & Toplam & 7 & 1 & 12 \\
\hline & & DFE & 1 & 0 & 2 \\
\hline & & FKİB & 5 & 1 & 6 \\
\hline & & KBD & 1 & 0 & 4 \\
\hline & & Genel Toplam & 25 & 1 & 29 \\
\hline
\end{tabular}

*Alt Öğrenme Alanlarl: HB: Hareket Becerileri, HKiB: Hareket Kavramlarl, Illkeleri ve İlgili Hayat Becerileri, HST: Hareket Strateji ve Taktikleri, DFE: Düzenli Fiziksel Etkinlik, FKiB: Fiziksel Etkinlik Kavramları, İlkeleri ve Illgili Hayat Becerileri, KBD: Kültürel Birikimlerimiz ve Değerlerimiz

Tablo 2 incelendiğinde tüm sınıf düzeylerinde "Hareket Yetkinliği" öğrenme alanı kazanımlarında $136 \mathrm{kez}(\% 65,38)$, “Aktif ve Sağlıklı Hayat” öğrenme alanı kazanımlarında 72 


\section{Ortaokul Beden Ĕ̆itimi ve Spor Dersi Öğretim Programı Kazanımlarının 21. Yüzyıl Becerileri Açısından İncelenmesi}

kez $(\% 34,62)$ 21. Yüzyıl becerilerine temas edildiği, her iki öğrenme alanında tüm sınıf kazanımlarında "Öğrenme ve Yenilikçilik Becerileri" ile "Yaşam ve Kariyer Becerileri” ne temas edilirken, "Bilgi, Medya ve Teknoloji Becerileri" ne ise sadece 7. ve 8.sinıflarda birer kazanımla temas edildiği görülmektedir. Yine Tablo 2 geneline bakıldığında; "Öğrenme ve Yenilikçilik Becerileri” ne en fazla "Hareket Yetkinliği (72)", en az ise "Aktif ve Sağlıklı Hayat (27) " öğrenme alanı kazanımlarında, "Yaşam ve Kariyer Becerileri” ne yine en fazla "Hareket Yetkinliği (64)", en az ise "Aktif ve Sağlıklı Hayat (43)" öğrenme alanı kazanımlarında yer verilirken, "Bilgi, Medya ve Teknoloji Becerileri" ne ise sadece "Aktif ve Sağlıklı Hayat (2)" öğrenme alanı kazanımlarında yer verilmiştir. Becerilerin öğrenme alanına göre dağılımı ş̧ekil 2' de gösterilmiştir.

Şekil 2: 21.yüzyıl becerilerinin ögrenme alanlarına göre dă̆glımı

2. Aktif ve Sağlıklı Hayat

1. Hareket Yetkinliği

\section{0}
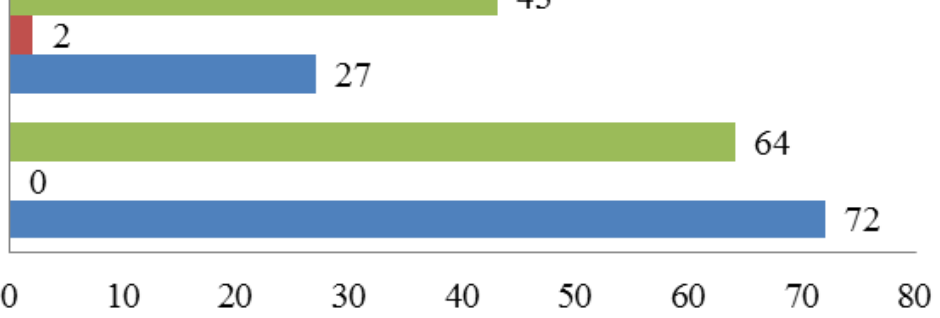

- Yaşam ve Kariyer Becerileri

m Öğrenme ve Yenilikçilik Becerileri

- Bilgi, Medya ve Teknoloji Becerileri

Tablo 3: Öğretim programı kazanımlarında 21. yüzyıl alt becerilerinin sinıflara göre dağıllımı

\begin{tabular}{|c|c|c|c|c|c|c|c|c|c|}
\hline \multirow{2}{*}{\multicolumn{2}{|c|}{ 21. yüzyıl becerileri }} & \multicolumn{2}{|c|}{ 5. Sinıf } & \multicolumn{2}{|c|}{ 6. Sinıf } & \multicolumn{2}{|c|}{ 7. Sinıf } & \multicolumn{2}{|c|}{ 8. Sinıf } \\
\hline & & $\mathbf{n}$ & $\%$ & $\mathbf{n}$ & $\%$ & $\mathbf{n}$ & $\%$ & $\mathbf{n}$ & $\%$ \\
\hline \multirow{3}{*}{$\begin{array}{l}\text { Öğrenme ve } \\
\text { Yenilikçilik } \\
\text { Becerileri }\end{array}$} & $\begin{array}{l}\text { Eleştirel Düşünme ve } \\
\text { Problem Çözme }\end{array}$ & 12 & 22,64 & 6 & 12,00 & 8 & 16,00 & 10 & 18,18 \\
\hline & Yaratıc1lık ve Yenilik & 6 & 11,32 & 10 & 20,00 & 9 & 18,00 & 3 & 5,45 \\
\hline & İletişim ve İşbirliği & 7 & 13,21 & 6 & 12,00 & 10 & 20,00 & 12 & 21,82 \\
\hline \multirow{3}{*}{$\begin{array}{l}\text { Bilgi, } \\
\text { Medya ve } \\
\text { Teknoloji } \\
\text { Becerileri }\end{array}$} & Bilgi Okuryazarlığı & 0 & 0,00 & 0 & 0,00 & 1 & 2,00 & 0 & 0,00 \\
\hline & Medya Okuryazarlığı & 0 & 0,00 & 0 & 0,00 & 0 & 0,00 & 1 & 1,82 \\
\hline & $\begin{array}{l}\text { Teknoloji } \\
\text { Okuryazarlığ1 }\end{array}$ & 0 & 0,00 & 0 & 0,00 & 0 & 0,00 & 0 & 0,00 \\
\hline \multirow{5}{*}{$\begin{array}{l}\text { Yaşam ve } \\
\text { Kariyer } \\
\text { Becerileri }\end{array}$} & Esneklik ve Uyum & 5 & 9,43 & 7 & 14,00 & 7 & 14,00 & 2 & 3,64 \\
\hline & $\begin{array}{l}\text { Girişimcilik ve } \\
\text { Özyönetim }\end{array}$ & 6 & 11,32 & 4 & 8,00 & 4 & 8,00 & 15 & 27,27 \\
\hline & $\begin{array}{l}\text { Sosyal ve Kültürlerarası } \\
\text { Beceriler }\end{array}$ & 6 & 11,32 & 7 & 14,00 & 6 & 12,00 & 7 & 12,73 \\
\hline & $\begin{array}{l}\text { Üretkenlik ve } \\
\text { Sorumluluk }\end{array}$ & 10 & 18,87 & 8 & 16,00 & 3 & 6,00 & 1 & 1,82 \\
\hline & Liderlik ve Sorumluluk & 1 & 1,89 & 2 & 4,00 & 2 & 4,00 & 4 & 7,27 \\
\hline
\end{tabular}




\begin{tabular}{lllllllll}
\hline Toplam & 53 & 100,0 & 50 & 100,0 & 50 & 100,0 & 55 & 100,0 \\
\hline
\end{tabular}

Tablo 3 incelendiğinde; sınıf düzeylerine göre öğretim programının kazanımlarında “Öğrenme ve Yenilikçilik Becerileri” başlığında eleştirel düşünme ve problem çözme becerilerine, 5.sinifta $\% 22,64,6 . \sin 1$ fta $\% 12,00,7$. sinifta $\% 16,00,8$. sinıfta $\% 18,18$, yaratıcilık ve yenilik becerilerine 5. sinıfta $\% 11,32,6$. sinıfta $\% 20,00,7$. sinıfta $\% 18,00,8$. sinıfta $\% 5,45$, iletişim ve işbirliği becerilerine ise $5 . \sin ı f t a ~ \% 13,21,6 . \sin ı f t a ~ \% 12,00,7$. sınıfta $\% 20,00,8$. sınıfta $\% 21,82$ oranında temas edildiği görülmektedir. "Bilgi, Medya ve Teknoloji Becerileri" başlığında bilgi okuryazarlığı becerilerine sadece 7 . sınıfta $\% 2,00$, medya okuryazarlığı becerilerine sadece 8 . sınıfta \%1,82 oranında temas edildiği, teknoloji okuryazarlığı becerilerine ise temas edilmediği görülmektedir. "Yaşam ve Kariyer Becerileri" başlı̆ı̆nda ise esneklik ve uyum becerilerine 5.sınıfta $\% 9,43,6$. ve $7 . \sin ı f t a ~ \% 14,00,8$. sinıfta $\% 3,64$, girişimcilik ve özyönetim becerilerine 5.sınıfta $\% 11,32,6$. ve $7 . \sin ı f t a ~ \% 8,00,8$. sinıfta $\% 27,27$, sosyal ve kültürlerarası becerilerine 5.sinıfta $\% 11,32,6$.sinıfta $\% 14,00,7$. sinıfta $\% 12,00,8$. sinıfta $\% 12,73$, üretkenlik ve sorumluluk becerilerine 5 .sinifta $\% 18,87,6$.sinifta $\% 16,00,7$. sinifta $\% 6,00,8$. sinifta $\% 1,82$, liderlik ve sorumluluk becerilerine ise $5 . \sin ı f t a 1,89,6$. ve $7 . \sin 1 \mathrm{fta} \% 4,00,8$. sinıfta $\% 7,27$ oranında temas edildiği görülmektedir.

Tablo 3' incelendiğinde; öğretim programı kazanımlarında $208 \mathrm{kez}$ temas edilen alt becerilerin genel dağılımına bakıldığında ise; en çok eleştirel düşünme ve problem çözme (36; $\% 17,31)$, en az ise medya ve bilgi okuryazarlığı $(1 ; \% 0,48)$ becerilerine temas edildiği, teknoloji okuryazarlığı becerilerine ise hiç temas edilmediği görülmektedir. Kazanımlarda, eleştirel düşünme ve problem çözme becerilerinden sonra sırasıyla; iletişim ve işbirliği $(35 ; \% 16,83)$, girişimcilik ve özyönetim $(29 ; \% 13,94)$, yaratıcılık ve yenilik $(28 ; \% 13,46)$, sosyal ve kültürlerarası beceriler $(26 ; \% 12,50)$, üretkenlik ve sorumluluk $(22 ; \% 10,58)$, esneklik ve uyum $(21 ; \% 10,10)$, liderlik ve sorumluluk $(9 ; \% 4,33)$ becerilerine temas edildiği tespit edilmiştir. 21. Yüzyıl becerilerinin alt becerilere göre dağılımı şekil 3' de verilmiştir.

Şekil 3: Öğretim programı kazanımlarında 21. yüzyıl alt becerilerinin genel dă̆ğlımı

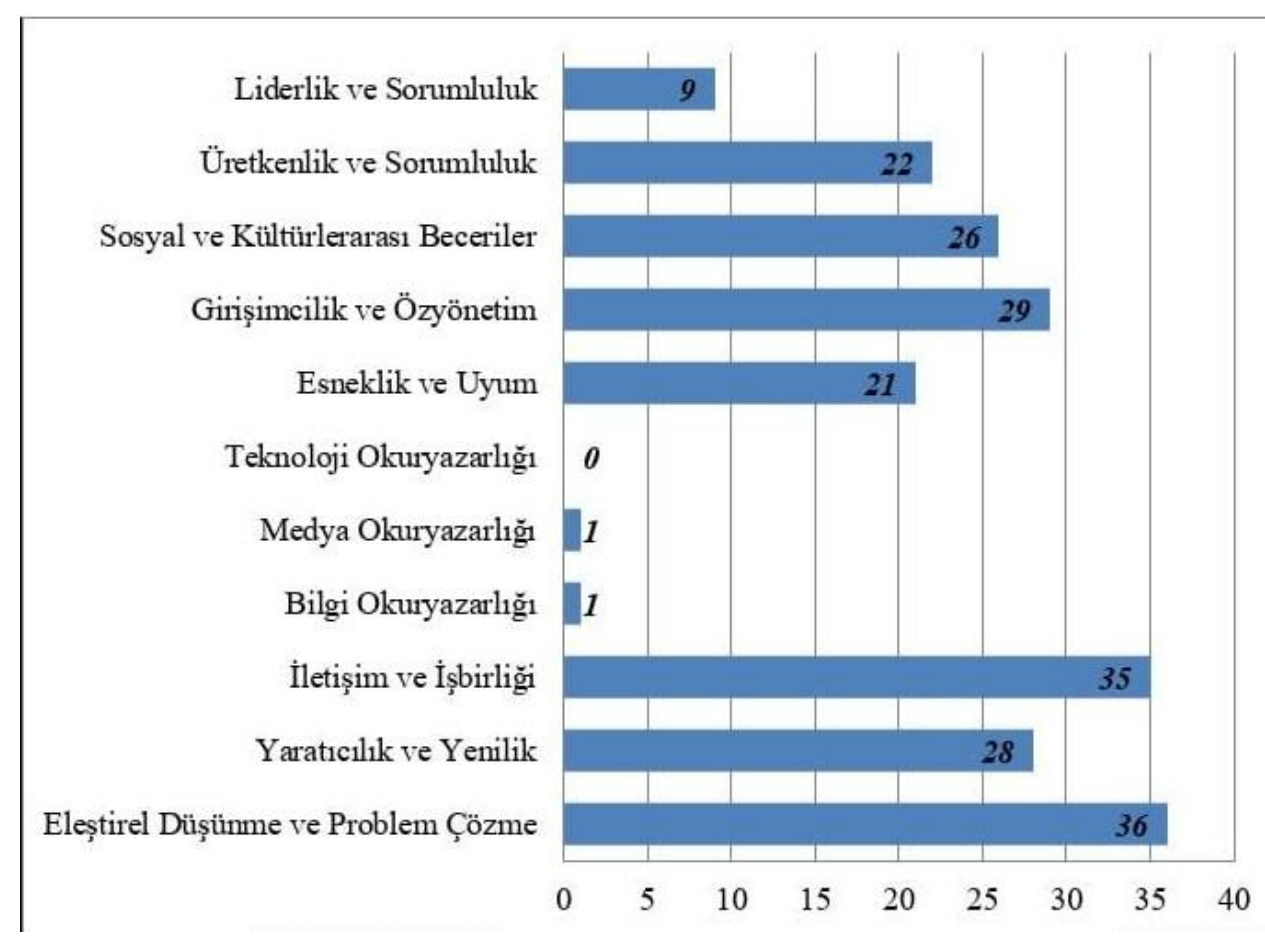

Artuklu Insan ve Toplum Bilim Dergisi, 2021/6 (1), 71-84. 


\section{Ortaokul Beden Ĕgitimi ve Spor Dersi Öğretim Programı Kazanımlarının 21. Yüzyıl Becerileri Açısından Íncelenmesi}

\section{SONUÇ}

Ortaokul (5, 6, 7 ve 8. Sinıflar) Beden Eğitimi ve Spor Dersi Öğretim Programı kazanımlarının 21. yüzyıl becerileri açısından incelendiği bu çalışmada; kazanımların birden çok beceriyle ilişkili olduğu, bu kapsamda kazanımlarda $208 \mathrm{kez} \mathrm{"21.} \mathrm{yüzyıl} \mathrm{becerisine"} \mathrm{yer} \mathrm{verildiği,}$ becerilerin en çok 8.sınıf sonra sırasıyla 5., 6. ve 7. sınıfların kazanımlarında yer aldığı görülmüştür. Programda ana başlıklar halinde 21. yüzyıl becerilerine en çok yaşam ve kariyer becerilerine, ardından öğrenme ve yenilikçilik becerilerine, en az ise bilgi, medya ve teknoloji becerilerine değinildiği ettiği tespit edilmiştir. Alt beceriler olarak ise en çok eleştirel düşünme ve problem çözme, en az ise medya ve bilgi okuryazarlığı becerilerine değinildiği, teknoloji okuryazarlığı becerilerine ise hiç değinilmediği saptanmıştır. Yine öğretim programı kazanımlarında tüm sınıf düzeylerinde "Hareket Yetkinliğı”" ve "Aktif ve Sağlıklı Hayat” öğrenme alanında "Öğrenme ve Yenilikçilik Becerileri" ile "Yaşam ve Kariyer Becerileri”" ne yer verilirken, "Bilgi, Medya ve Teknoloji Becerileri" ne ise sadece 7. ve 8.sınıflarda yer verildiği sonucuna ulaşılmıştır.

Araştırmamızda ortaokul beden eğitimi ve spor dersi öğretim programının kazanımları 21. yüzyıl becerileri açısından incelenmiş olup, başlık ve alt başlıklar halinde bu becerilerin incelendiği başka çalışmaya rastlanılmadığından, çalışmamızın sonuçları diğer derslerin öğretim programlarına dönük yapılan benzer çalışma sonuçları ile karşılaştırılmaya çalışılmıştır. Bu kapsamda literatür incelendiğinde, öğretim programları ekseninde bir bütünlük arz eden benzer sonuçların olduğu görülmektedir. Kurudayığlu ve Soysal (2019) 2018 Türkçe dersi öğretim programı kazanımlarını 21. yüzyıl becerileri açısından incelendikleri çalışmalarında, kazanımlarda en çok "Öğrenme ve Yenilikçilik Becerilerine", sonra "Yaşam ve Kariyer Becerilerine", en az ise "Bilgi, Medya ve Teknoloji Becerilerine" yer verildiğini tespit etmişlerdir. Kalemkuş (2020) üçüncü ve dördüncü sınıflar kapsamında fen bilimleri dersi öğretim programı kazanımlarını 21.yüzyıl becerileri açısından incelediği araştırmasında, her iki sınıf seviyesinde yer alan kazanımların çoğunlukla eleştirel düşünme ve problem çözme becerisini geliştirmeye yönelik olduğunu, her iki sınıf seviyesinde bilgi iletişim ve teknoloji okuryazarlığı becerisine yönelik herhangi bir kazanımın olmadığını ayrıca programda yer alan kazanımların çoğunlukla birden fazla beceriyi kapsadığını belirtmiştir.

Bal (2018) Türkçe dersini 21. yüzyıl becerileri açısından incelendiği çalışmasında, programda 21. yüzyıl becerilerinden en çok öğrenme ve yenilik becerilerinin yer aldığı ancak bilgi, medya ve teknoloji ile yaşam ve kariyer beceri alanlarının ihmal edildiğini saptamıştır. Benzer şekilde Kayhan ve ark. (2019) 2018 Türkçe dersi öğretim programı 8.sınıf kazanımlarını 21.yüzyıl becerileri açısından incelediği araştırmasında, "Öğrenme ve Yenilik İle Yaşam ve Kariyer Becerilerine" çoğunlukla , "Bilgi, Medya ve Teknoloji Becerilerine" ise daha az yer verildiğini ancak becerilerin dengeli bir dağılıma sahip olmadığını belirlemişlerdir. Çelebi ve Altuncu (2019) 9.sınıf İngilizce öğretim programında, medya okuryazarlığı ve bilgi teknoloji okuryazarlığı becerilerine yönelik çok az sayıda kazanım olduğunu, Koçin ve Tuğluk (2020) ise, 2013 okul öncesi eğitim programında günümüzde oldukça önem kazanan ve 21. yüzyll becerileri içerisinde vurgulanan teknoloji ve medya okuryazarlığ ile ilgili kazanımlara pek rastlanılmadığı yönünde görüş bildirmişlerdir. Kardeş (2020) okul öncesi eğitim programının 21. yüzyıl becerileri ve STEAM eğitimi bağlamında incelediği araştırmasında da, programda teknoloji kullanımının yetersiz olduğunu ve çocukları derin düşünmeye sevk edecek merak ve proje tabanlı uygulamaların yeterli olmadığını ifade etmektedir. Öğretim programlarına yön veren öğretmenler ise, 21. yüzyıl becerilerini, teknolojiyi kullanma becerisi ve teknolojik ilerleme olarak tanımlamışlardı (Eser ve Bozcan, 2019; Hamlı ve ark., 2020). 


\section{E. IŞIKGÖZ}

Alan yazın araştırma sonuçları, araştırma bulgularımızla büyük ölçüde paralellik göstermektedir. Ülkemizde öğretim programlarının, esnek ve çerçeve bir yapıda merkezi olarak MEB Talim ve Terbiye Kurulunca belirlenmesi, bir bütünlük içerisinde programların aşamalılık ilkesini barındırması ve "Türkiye Yeterlilikler Çerçevesinde (TYÇ, 2015)" belirlenen sekiz anahtar yetkinliğin programlarda ortak olarak yer alması nedeniyle, öğretim programlarına yönelik düzenlenen araştırmaların benzer sonuçlar üretmesine neden olduğu düşünülmektedir. Öğretim programlarının her sınıf düzeyindeki öğrenme ve alt öğrenme alanlarına göre belirlenen kazanımların farklı nitelikte yetkinlik ve/veya beceriyi içerebilmesi mümkündür. Ancak gerek bu çalı̧̧mada ve gerekse diğer çalışmalarda; 21. yüzyıl becerilerinin programlarda dengeli ve bazı beceriler açısından yeterli bir şekilde dağılmaması, özellikle teknoloji okuryazarlığı becerilerine çok az sayıda yer verilmesi dikkati çekmektedir. Oysa çağımızın her alanda giderek artan özelliği teknoloji diğer bir ifade dijital çağı olmasıdır. Bu duruma Gelen (2017), bazı kavramlar, beceriler ve değerler açısından P21 ile örtüşen MEB öğretim programların, P21''in birbirini tamamlayan anlamlı bir sistem içinde çalışan öğrenme çıktıları destek sistemlerinden oluşan yapısı gözetilerek geliştirilmesi ve uygulanması gerekliliğine vurgu yapmaktadır.

Bireylerin bilgi teknolojilerini kullanmaları için dijital yetkinliğe, teknoloji ve/veya dijital okuryazarlık becerilerine sahip olmalarının gerekliliği bilinen bir gerçekliktir. Nitekim öğretim programının yetkinlikler kısmında yer verilen dijital yetkinlik "İ̧̧, günlük hayat ve iletişsim için bilgi iletişsim teknolojilerinin güvenli ve eleştirel şekilde kullanılmasinı kapsar. Söz konusu yetkinlik, bilgiye erişim ve bilginin değerlendirilmesi, saklanması, üretimi, sunulması ve alışveriş̧i için bilgisayarların kullanılması ayrıca internet aracıllğıyla ortak ağlara katılım sağlanması ve iletişim kurulması gibi temel beceriler yoluyla desteklenmektedir" ş̧eklinde tanımlanmıştır. Eğitim teknolojilerinin etkin kullanıldığı, Bilgi ve İletişim Teknolojileri (BİT) entegrasyonu yapılan, öğrenmenin sorumluluğunu öğrenene veren bir eğitim sistemi ile ancak 21. yüzyıla hazırlanılabilir (Sağıroğlu ve ark., 2020). Çünkü günümüz dünyası çok yönlü, çok merkezli, sürekli değişen ve giderek karmaşıklaşan bir yapıya doğru ilerlemektedir. Bu süreçte bilgi toplumundan beceri toplumuna geçileceği ve geleceğin becerilerine odaklanılacağı dile getirilmektedir (Güneş ve Deveci, 2020). Nitekim hızla değişen ve gelişen dünyada, yeterli bir bilgi ve beceri ediniminden söz etmek mümkün olmamakta, bugün öğrenilenlerin yarın geliştirilmesi ve güncellenmesinin gerektiği bir bilgi çağındayız (Kızılkaya, 2021).

21. yüzyıl becerilerine diğer derslerin öğretim programlarında olduğu gibi beden eğitimi ve spor dersi öğretim programında da yeterli ve dengeli bir biçimde yer alması, özellikle ortaokul beden eğitimi ve spor dersi öğretim programında yer verilecek becerilerin lise kademesinde anlam bulması ve pekiştirilmesi açısından önem taşımaktadır. 2010 yılında gerçekleştirilen "Beden Eğitimi Pedagojisi 2010 Küresel Toplantısı (GoFPEP 2010)" nda; Giderek artan küreselleşme, bilgi patlaması ve demografik özelliklerdeki değişim, 21. yüzyılda yaşamak, çalışmak ve oyun oynamak için gerekli olan bilgi, beceri ve eğilimler üzerinde önemli bir etkiye sahip olduğu vurgulanmıştır. Bu noktada çocuk ve gençlerin; eleştirel düşünme ve problem çözme becerilerini kazanmalarını, çevre koşullarına uyum sağlamalarını, bilgiyi etkili biçimde analiz etmelerini, sözlü ve yazılı olarak farklı şekillerde iletişim kurmalarını, düşünürken merak, hayal gücü (imgelem) ve yaratıcılık özelliklerini daha çok yansıtmalarını, sağlıklı aktif bir yaşam tarzı geliştirmelerini gerektirdiği konusunda görüş birliğine varıldığı görülmüştür. Ayrıca sağlık ve beden eğitiminin öğretiminde teknoloji uygulamalarının gözden geçirilmesi, beden eğitimi öğretiminde bireyselleştirilmiş öğrenme süreçleri ve değerlendirmeyi desteklemek için teknolojiyi kullanmak, öğrenme olanaklarını vurgulamak için etkili teknoloji ve yansıtma kullanımını teşvik etmek, teori ile uygulama arasında bağ kurmak gibi, konularında da görüș birliğine varılmıştır (Edginton ve ark., 2010). Bu kapsamda program güncelleme çalışmaları esnasında, ortaokul beden eğitimi ve spor öğretim programında 21. yüzyıl becerilerinin dengeli bir şekilde dağılması, özellikle bilgi, 


\section{Ortaokul Beden Ĕ̆itimi ve Spor Dersi Öğretim Programı Kazanımlarının 21. Yüzyıl Becerileri Açısından İncelenmesi}

medya ve teknoloji becerilerine yeterli sayıda yer verilmesi önerilmektedir. Nitekim Kalemkuş (2021)' da araştırmasında, tüm dersler için öğretim programları oluşturulurken bu programlarda yer alacak kazanımlar için 21. yüzyıl becerilerinin göz önünde bulundurulmasının günümüzün becerilerini edinmede öğrencilere firsat sunacağı beklentisini dile getirmiştir. Hamarat (2019) ise ders içerikleri ve müfredatlarda genel çerçeve muhafaza edilirken içerik bilgi yoğun bir yapıdan sıyrılıp daha çok eyleme geçiren, düşündüren, bağlantı kurduran niteliğe kavuşturulmasını önermiş̧ir.

\section{KAYNAKÇA}

Ananiadou, K. and M. Claro (2009). 21st Century Skills and Competences for New Millennium Learners in OECD Countries. OECD Education Working Papers, No. 41, OECD Publishing, Paris.

Aykaç, M., Günaydın, L. ve Yılmaz, İ.A. (2011). Yeni Eğitim paradigması ve Bilgi Toplumunda Üniversiteler. 2. Uluslararası 6. Ulusal Meslek Yüksekokulları Sempozyumu. 25-27 Mayıs, Aydin.

Bal, M. (2018). Türkçe Dersinin 21. Yüzyıl Becerileri Açısından İncelenmesi. Turkish Studies, 13 (4), 49-64.

Barası, M. ve Erdamar, G. (2021). 2018 Ortaokul Türkçe Dersi Öğretim Programının 21. yüzyıl Becerileri Açısından İncelenmesi: Öğretmen Görüşleri. Bolu Abant İzzet Baysal Üniversitesi Eğitim Fakültesi Dergisi, 21(1), 222-242.

Binkley, M., Erstad, O., Hermna, J., Raizen, S., Ripley, M., Miller-Ricci, M. and Rumble, M. (2012). Defining Twenty-First Century Skills. In Griffin, P., Care, E. and McGaw, B. Assessment and Teaching of 21st Century Skills, Dordrecht, Springer.

Cansoy, R. (2018). Uluslararası Çerçevelere Göre 21. Yüzyıl Becerileri ve Eğitim Sisteminde Kazandırılması. Insan ve Toplum Bilimleri Araştırmaları Dergisi, 7(4), 3112-3134.

Çelebi, M. ve Altuncu, N. (2019). 21. Yüzyll Becerilerinin Ingilizce Öğretim Programındaki Yeri. 6. Uluslararası Multidisipliner Çalışmaları Kongresi. 26-27 Nisan, Gaziantep, Türkiye

Çepni, S. (2018). Kuramdan Uygulamaya STEM+A+E eğitimi. Ankara: Pegem Akademi.

Çetin, M. ve Çetin, G. (2021). 21. Yüzyıl Becerileri Açısından MEB Okul Öncesi Eğitim Programına Eleştirel Bir Bakış. Yaşadıkça Eğitim, 35(1), 235-255.

Çınar, O., Teyfur, E. ve Teyfur, M. (2006). İlköğretim Okulu Öğretmen ve Yöneticilerinin Yapılandırmacı Eğitim Yaklaşımı ve Programı Hakkındaki Görüşleri. İnönü Üniversitesi Eğitim Fakültesi Dergisi, 7(11), 47-64.

Edginton, C.R., Chin, M.K. ve Demirhan, G. (2010). Beden eğitimi ve sağllk: Yeni bir küresel görüş birliği. Spor Bilimleri Dergisi, 21(3), 122-128.

Eryılmaz, S. ve Uluyol, Ç. (2015). 21. Yüzyıl Becerileri Iş̧ı̆ında FATïH Projesi Değerlendirmesi. Gazi Üniversitesi Gazi Eğitim Fakültesi Dergisi, 35(2), 209-229.

Eser, B. ve Bozcan, E.Ü. (2019). Okul Öncesi Dönemde 21. Yüzyll Becerilerinin Öğretmen Görüşlerine Göre İncelenmesi. 5. Uluslararası TURKCESS Eğitim ve Sosyal Bilimler Kongresi, 27-29 Haziran, İstanbul. 
EU (2008). Recommendations of the European Parliament and of the Council of 23 April 2008 on the Establishment of the European Qualifications Framework for Lifelong Learning. Official Journal of the European Union, (2008/C 111/1-4).

Gelen, İ. (2017). P21-Program ve Öğretimde 21. Yüzyıl Beceri Çerçeveleri (ABD Uygulamaları). Disiplinlerarası Eğitim Araştırmaları Dergisi, 1(2), 15-29.

Gelişli, Y. ve Doğan, E. (2020). Türk Dili ve Edebiyatı Ortaöğretim Programına 21. Yüzyıl Becerilerinin Yansıması. TURAN-SAM Uluslararası Bilimsel Hakemli Dergisi, 12(47), 58-69.

Güneş, F. ve Deveci, T. (2020). Yetişkin Ĕgitimi Ve Hayat Boyu Öğrenme. Ankara: Pegem Akademi.

Hamarat, E. (2019). 21. Yüzyıl Becerileri Odağında Türkiye’nin Eğitim Politikaları. SETA Analiz, Sayı: 272. Erişim: https://www.setav.org/analiz-21-yuzyil-becerileri-odaginda-turkiyeninegitim-politikalari/, Erişim tarihi: 10.03.2021

Hamlı, D., Hamlı, S. ve Taneri, P.O. (2020). Temel eğitimde 21. yüzyıl becerilerinin sınıf ögretmenlerinin görüşlerine göre incelenmesi. Current Debates on Social Sciences 4Multidisciplinary Studies (Edt: Alpaslan Ceylan, İlhami Durmuş ve Salih Çeçen), Ankara: Bilgin Kültür Sanat Yayınları.

ISTE (2014). ISTE-standards for students. Erişim: https://www.iste.org/standards/forstudents, Erişim tarihi: 10.03.2021

Kalemkuş, J. (2021). Fen Bilimleri Dersi Öğretim Programı Kazanımlarının 21.Yüzyıl Becerileri Açısından İncelenmesi. Anadolu Journal of Educational Sciences International, 11(1), 63-87.

Karabacak K. (2017). Ĕgitime İlişkin Temel Kavramlar. A. Arslan (Ed.). Eğitim Bilimine Giriş içinde (3-22). Ankara: Nobel Yayınları.

Kardeş, S. (2020). Okul Öncesi Eğitim Programının 21. Yüzyıl Becerileri ve STEAM Eğitimi Bağlamında İncelenmesi. Eğitimde Kuram ve Uygulama, 16(2), 109-119.

Kayhan, E., Altun, S. ve Gürol, M. (2019). Sekizinci Sınıf Türkçe Öğretim Programı (2018)'Nın 21. Yüzyıl Becerileri Açısından Değerlendirilmesi. Adnan Menderes Üniversitesi Ĕ̆itim Fakültesi Eğitim Bilimleri Dergisi, 10(2), 20-35.

Kızılkaya, H. (2021). Program Geliştirme Çalışmaları Üzerine Bir Değerlendirme: İngiltere Ulusal Program1. Turkish Journal of Educational Studies, 8(1), 68-84.

Koçin, B. ve Tuğluk, M.N. (2020). 2013 Okul Öncesi Eğitim Programının 21. Yüzyıl Becerileri Açısından İncelenmesi. Ulakbilge Sosyal Bilimler Dergisi, 49, 621-649.

Kurudayığlu, M. ve Soysal, T. (2019). 2018 Türkçe Dersi Öğretim Programı Kazanımlarının 21. Yüzyıl Becerileri Açısından İncelenmesi. Ahi Evran Üniversitesi Sosyal Bilimler Enstitüsü Dergisi, 5(2), 483-496.

MEB (2011). Eğitimi Araştırma ve Geliştirme Başkanlığı. MEB 21. Yüzyıl Öğrenci Profili. Erişim: https://www.egitimedestek.meb.gov.tr/earged/earged/21.\%20yy_og_pro.pdf, Erişim tarihi: 10.02.2021

MEB (2017). Müfredatta Yenileme ve Değişiklik Çalışmalarımız Üzerine. Erişim: https://ttkb.meb.gov.tr/meb_iys_dosyalar/2017_07/18160003_basin_aciklamasi-program.pdf, Erişim tarihi: 10.03.2021, 


\section{Ortaokul Beden Ĕ̆itimi ve Spor Dersi Öğretim Programı Kazanımlarının 21. Yüzyıl Becerileri Açısından İncelenmesi}

MEB (2018a). Beden Eğitimi ve Spor Dersi Öğretim Programı (Ortaokul 5, 6, 7 ve 8 . Sinıflar). Erişim: http://mufredat.meb.gov.tr/ProgramDetay.aspx?PID=324, Erişim tarihi: 14.02.2021

MEB (2018b). 2023 Eğitim Vizyonu. Erişim: http://2023vizyonu.meb.gov.tr/doc/2023 EGITIM_VIZYONU.pdf, Erişim tarihi: 10.03.2021

Miles, M.B. and Huberman, A.M. (1994). Qualitative Data Analysis: an Expanded Sourcebook. CA: Sage Publications.

National Research Council. (2010). Exploring the intersection of science education and 21st century skills: A workshop summary. M. Hilton (Ed.). Washington DC: National Academy Press.

North Central Regional Educational Laboratory -NCREL (2003). 21st Century Skills. Erişim: www.ncrel.org/engauge/skills/skills.htm, Erişim tarihi: 10.03.2021

OECD (2018). The Future Of Education And Skills: Education 2030. Erişim: https://www.oecd.org/education/2030/E2030\%20Position\%20Paper\%20(05.04.2018).pdf, Erişim tarihi: 20.0 .2021

Oğuz, O., Oktay, A. ve Ayhan, H. (2010). 21. yüzyllda eğitim ve Türk eğitim sistemi. Ankara: Pegem Akademi Yayıncılık.

P21 (2019) Partnership for 21st Century Learning. Framework for 21st Century Learning (P21). Erişim: http://static.battelleforkids.org/documents/p21/P21_Framework_Brief.pdf Erişim tarihi: 10.01.2021

Sağıroğlu, Ş., Bülbül, H.İ., Kılıç, A. ve Küçükali, M. (2020). Dijital okuryazarlık. Ankara: Nobel Yayıncilık.

Selvi, Ö. (2012). Bilgi toplumu, bilgi yönetimi ve halkla ilişkiler. Gümüşhane Üniversitesi Iletişim Fakültesi Elektronik Dergisi, 3, 191-214.

Trilling, B. and Fadel, C. (2009). 21st Century Skills: Learning For Life in Our Times. Francisco: Jossey-Bass.

Tutkun, Ö.F. (2010). 21. Yüzyılda Eğitim Programının Felsefi Boyutları. Gazi Üniversitesi Gazi Eğitim Fakültesi Dergisi, 30(3), 993-1016.

TÜSİAD (2012). Türk Sanayicileri ve İş adamları Derneği. Erişim: https://tusiad.org/tr/basin-bultenleri/item/5681-tusiad-21--yuzyil-becerileri-ve-egitimin-niteligikonulu-toplanti-dizisi-baslatiyor, Erişim tarihi: 10.03.2021

TYÇ (2015). Türkiye Yeterlilikler Çerçevesi. Erişim: https://www.myk.gov.tr/index.php/tr/turkiye-yeterlilikler-cercevesi, Erişim tarihi: 10.03.2021

Uçak, S. ve Erdem, H. H. (2020). Eğitimde Yeni Bir Yön Arayışı Bağlamında "21. Yüzyıl Becerileri ve Eğitim Felsefesi”. Uş̧ak Üniversitesi Ĕ̈itim Araşstırmaları Dergisi, 6(1), 76-93.

Yalı, S. (2021). 21. Yüzyıl Becerileri Perspektifinden Tarih Eğitiminin Yönü. İnsan ve Insan, 8(27), 209-233.

Yıldırım, A. ve Şimşek, H. (2006). Sosyal Bilimlerde Nitel Araştırma Yöntemleri, Ankara: Seçkin Yayıncıllk. 